\title{
BIOMEDICAL ENGINEERING METHODS AS POTENTIAL TREATMENT OPTIONS FOR INTERVERTEBRAL DISC DEGENERATION
}

\author{
Shu-HuA YANG ${ }^{1,2}$, Feng-Huei LiN ${ }^{1}$ \\ ${ }^{1}$ Institute of Biomedical Engineering, College of Engineering and College of Medicine, National \\ Taiwan University, Taipei, Taiwan \\ ${ }^{2}$ Department of Orthopedics, National Taiwan University Hospital, Taipei, Taiwan
}

\begin{abstract}
Degeneration of the intervertebral disc (IVD) and associated spinal disorders are a leading cause of morbidity resulting in substantial pain and increased health cost. Current treatment options may relieve some clinical symptoms but will never stop further degeneration in the IVD. In recent years, several investigations have been carried out trying to regenerate IVD tissue. These biomedical engineering methods aim to retard or even reverse the degenerative process and possibly regain a healthy IVD. In this review, recent progresses on each category of biomedical engineering approaches will be briefly introduced.
\end{abstract}

Biomed Eng Appl Basis Comm, 2005 (April); 17: 38-43.

Keywords: Intervertebral disc, Degeneration, Biomedical Engineering, Regeneration

\section{INTERVERTEBRAL DISC DEGENERATION}

The intervertebral disc (IVD) has a composite structure comprised of a nucleus pulposus (NP) core, a multi-layered lamina of annulus fibrosus (AF), and cartilaginous end plates. Degeneration of the IVD and associated spinal disorders are a leading cause of morbidity resulting in substantial pain and increased health cost [1-2]. Although the causes and pathophysiology of IVD degeneration are mostly unknown, some evidence indicates that IVD degeneration originates from NP [3-4]. As the IVD degeneration progresses, glycoaminoglycans (GAG) in the NP tissue are degraded gradually and the

Received: Feb 2, 2005; Accepted: Feb 20, 2005

Correspondence: Feng-Huei Lin, Professor

Institute of Biomedical Engineering,

College of Engineering and College of Medicine,

National Taiwan University, Taipei, Taiwan

E-mail: double@ha.mc.ntu.edu.tw continuous decrease of GAG content leads to progressive dehydration [5-6]. As the water binding capacity of the NP decreases, the IVD becomes deflated and more fibrous, which results in a compromised ability to transmit intervertebral forces optimally. The excessive compression load will eventually lead to damages in the AF. Fragments of the NP will then migrate and herniate through the defect in the AF, causing compression to nerve roots. When nucleotomy or disectomy is carried out for eliminating back and leg pain resulting from IVD herniation, almost no regeneration of the NP and the AF will occur. Therefore, degeneration of the IVD is inevitable [7-8].

In recent years, several investigations have been carried out for regeneration of IVDs. These biomedical engineering methods aim to retard or even reverse the degenerative process and possibly regain a healthy IVD. In this review, recent progresses on each research category will be briefly introduced. 


\section{GROWTH FACTOR TREATMENTS}

Growth factors are polypeptides that are involved in the modulation of cell growth and differentiation [9] and also in the regulation of matrix production and repair by various types of cells [10]. IVD cells modulate their metabolic activities by a variety of substances including cytokines, enzymes, enzyme inhibitors, and growth factors in a paracrine and/or autocrine fashion [11]. The degeneration of IVD may result from an imbalance between the anabolic and catabolic processes. Alteration in both anabolic and catabolic processes are thought to play key roles in the onset and progression of IVD degeneration, but the biochemical processes that regulate these changes are poorly understood. The anabolic regulators of IVD include insulin-like growth factor-1 (IGF-1) [12], transforming growth factor- $\beta$ (TGF- $\beta$ ), basic fibroblast growth factor (bFGF) and the bone morphogenetic proteins (BMPs) [13]. Based on the in vitro and in vivo data, the clinical application of growth factors by direct injection of the protein into the intervertebral disc could be a feasible new therapeutic option for treatment of IVD degeneration. However, the dose required and the frequency and mode of delivery should be further investigated [13].

\section{GENE THERAPY}

Gene-based therapy involves the transfer of genetic material into a target cell for replacement of a defective sequence to modulate the immune system or the production of a beneficial substance [14]. Successful transduction had been demonstrated in human IVD cells [15]. Genes which had been used for transducing IVD cells included growth factors, cellular regulators, and tissue inhibitors of matrix metalloproteinase (TIMP). IVD cells which were transfected by genes for TGF- $\beta 1$ [16], IGF-1, and BMP-2 [17] showed a significant increase in proteoglycan synthesis. An addictive effect was revealed in combination gene transfer [17]. Gene transfer of TIMP-1 to IVD cells could increase proteoglycan synthesis as well [18]. Sox9 have been demonstrated to be an essential transcription factor for type 2 collagen synthesis [19]. Gene transfer of Sox 9 to IVD cells has demonstrated an increase in concentration of type 2 collagen [20]. LIM Mineralization Protein-1 (LMP-1) is known to induce the secretion of multiple different BMPs [21-22]. Transfer LMP-1 gene to IVD cells could generate a chondrogenic effect including increase in expression of aggrecan mRNA and proteoglycan synthesis [23]. Although gene therapy has proven its ability to beneficially modulate the IVD cells, safety concerns on viral vectors need further investigation before its clinical application. Besides, low cell density in the IVD is the other obstacle for the potential usage of gene therapy as well as growth factor treatment.

\section{AUTOLOGOUS DISC CHONDROCYTES TRANSPLANTATION (ADCT)}

Autologous disc chondrocyte transplantation (ADCT) had been approved to treat IVD degeneration in Germany since 1997 [24]. This cell-based therapeutics is the only biologic treatment method practiced clinically up to now. The procedure of ADCT is straightforward when surgical discectomy is indicated for the treatment of IVD herniation. The IVD material recovered in surgery is sent for tissue culturing and returned at a later date for percutaneous transplantation. The standard interval between discectomy and cell transplantation has yet to be optimized, but it is important to affirm annulus healing prior to cell transplantation. A time interval of 8-12 weeks has been acceptable to the outcome. Clinical studies had revealed sustained symptomatic relief and MRI had demonstrated anatomical recovery in some cases with heightened nuclear signal.

\section{COMBINATION OF CELLS AND BIOACTIVE SCAFFOLDS}

In addition to cell transplantation, it is theoretically more ideal to corporate cultured IVD cells with bioactive scaffolds which could help preserving phenotype of IVD cells and promoting matrix synthesis. There have been a few studies that have cultured human or animal IVD cells on various bioactive scaffolds in vitro [25-32]. But searching for ideal compositions of bioactive scaffold for 3dimensional culture of IVD cells with persistent manifestation of cell proliferation and viability as well as production of ECM is an ongoing task and the answer is still ambivalent. A bioactive scaffold usually composes of scaffold substrate and bioactive molecules. Materials which had been investigated as scaffold substrate in the literature include collagen, agarose, arginate, fibrin, bioglass, and gelatin. These scaffold substrates aim to provide highly porous structure in order to enhance cell attachment and subsequent proliferation. Hyaluronan and chondroitin are most common bioactive molecules incorporated into scaffold substrate. Hyaluronan had been showed regulating collagen fibrillogenesis [33] and stimulating chondrocytes to proliferate and synthesize 
proteoglycan [34]. Chondroitin-6-sulfate can upregulate the secretion of chondroitin sulfate and hyaluronan in the cartilage lineage cells [35]. By cultivated IVD cells in these bioactive scaffolds, part or whole IVD tissue is expected to replace degenerative IVD tissue or fill up the nucleotomized space.

\section{CONCLUSION}

Because the mechanism of IVD degeneration and back pain is poorly understood, pessimistic researchers usually question about the clinical outcome when applying a regenerative effort in a degenerative IVD. However, regeneration and functional recovery of degenerative IVD disease are always superior to and more attractive than discectomy and spinal fusion. Biomedical engineering approaches are the promising research frontier that warrants further investigation efforts to prove their efficacy on regenerating IVD tissue and eliminating discogenic disorders.

\section{REFERENCES}

1. D. Epidemiology, etiology, diagnostic evaluation, and treatment of low back pain. Curr Opin Rheumatol 1992;4:226-32.

2. Waddell G. Low back pain: a twentieth century health care enigma. Spine 1996;21:2820-5.

3. Adler JH, Schoenbaum M, Silberberg R. Early onset of disk degeneration and spondylosis in sand rats (Psammomys obesus) Vet Pathol 1983;20:13-22.

4. Silberberg R, Aufdermaur M, Adler JH. Degeneration of the intervertebral disks and spondylosis in aging sand rats. Arch Pathol Lab Med 1979;103:231-5.

5. Buckwalter JA. Aging and degeneration of the human intervertebral disc. Spine 1995;20:1307-14.

6. Pearce RH, Grimmer BJ, Adams ME. Degeneration and the chemical composition of the human intervertebral disc. J Orthop Res 1987;5:198-205.

7. Lipson SJ, Muir H. Experimental intervertebral disc degeneration: morphologic and proteoglycan changes over time. Arthritis Rheum 1981;24:12-21.

8. Mochida J, Nishimura K, Nomura T, Toh E, Chiba $M$. The importance of preserving disc structure in surgical approaches to lumbar disc herniation. Spine 1996;21:1556-63.

9. Favoni RE, de Cupis A. The role of polypeptide growth factors in human carcinomas: new targets for a novel pharmacological approach. Pharmacol Rev 2000;52:179-206.
10. Reddi AH. Bone morphogenetic proteins: from basic science to clinical applications. J Bone Joint Surg Am 2001;83(suppl 1):1-6.

11. Masuda K, Oegema TR, An HS. Growth factors and treatment of intervertebral disc degeneration. Spine 2004;29:2757-69.

12. Osada R, Ohshima H, Ishihara H, Yudoh K, Sakai $\mathrm{K}$, Matsui H, Tsuji H. Autocrine/paracrine mechanism of isulin-like growth factor-1 secretion, and the effect of isulin-like growth factor-1 on proteoglycan synthesis in bovine intervertebral discs. J Orthop Res 1996;14:690-9.

13. Thompson JP, Oegema TJ, Bradford DS. Stimulation of mature canine intervertebral disc by growth factors. Spine 1991;16:253-60.

14. Shimer AL, Chadderdon RC, Gilbertson LG, Kang JD. Gene therapy approaches for intervertebral disc degeneration. Spine 2004;29:2770-8.

15. Moon SH, Gilbertson LG, Nishida K, Knaub M, Muzzonigro T, Robbins PD, Evans CH, Kang JD. Human intervertebral disc cells are genetically modifiable by adenovirus-mediated gene transfer. Spine 2000;25:2573-9.

16. Moon SH, Nishida K, Gilbertson LG, et al. Responsiveness of human intervertebral disc cells to adenovirus mediated transfer of TGF- $\beta 1 \mathrm{cDNA}$ in $2 \mathrm{D}$ and $3 \mathrm{D}$ culture system: comparison to exogenous TGF- $\beta 1$. Presented at International Society for the Study of the Lumbar Spine meeting; Adelaide, Australia; 2002.

17. Moon S, Nishida K, Gilbertson LG, et al. Biologic response of human intervertebral disc cell to gene therapy cocktail. Presented at Orthopaedic Research Society meeting; San Francisco, CA, USA, 2001.

18. Wallach CJ, Sobajima S, Watanabe Y, Kim JS, Georgescu HI, Robbins P, Gilbertson LG, Kang JD. Gene transfer of the catabolic inhibitor TIMP-1 increases measured proteoglycans in cells from human intervertebral discs. Spine 2003;28:2331-7.

19. Bell DM, Leung KK, Wheatley SC, Ng LJ, Zhou S, Ling KW, Sham MH, Koopman P, Tam PP, Cheah KS. SOX9 directly regulates the type 2 collagen gene. Nat Genet 1997;16:174-8.

20. Paul R, Haydon RC, Cheng H, Ishikawa A, Nenadovich N, Jiang W, Zhou L, Breyer B, Feng T, Gupta P, He TC, Phillips FM. Potential use of Sox9 gene therapy for intervertebral disc degenerative disease. Spine 2003;28:775-63.

21. Boden SD, Lin Y, Hair GA, Helms JA, Hu D, Racine M, Nanes MS, Titus L. LMP-1, a LIMdomain protein, mediates BMP-6 effects on bone formation. Endocrinology 1998;139:5125-34. 
22. Minamide A, Boden SD, Viggeswarapu M, Hair GA, Oliver C, Titus L. Mechanism of bone formation with gene transfer of the cDNA encoding for the intracellular protein LMP-1: evidence for induction of multiple BMPs. J Bone Joint Surg Am 2003;85:1030-9.

23. Yoon ST, Park JS, Kim KS, Li J, Attallah-Wasif ES, Hutton WC, Boden SD. ISSLS Prize Winner: LMP-1 upregulates intervertebral disc cell production of proteoglycan and BMPs in vitro and in vivo. Spine 2004;29:2603-11.

24. Ganey TM, Meisel HJ. A potential role for cellbased therapeutics in the treatment of intervertebral disc herniation. Eur Spine J 2002;11:S206-14.

25. Alini M, Li W, Markovic P, Aebi M, Spiro RC, Roughley PJ. The potential and limitations of a cell-seeded collagen/hyaluronan scaffold to engineer an intervertebral disc-like matrix. Spine 2003;28:446-54.

26. Gruber HE, Fisher EC Jr, Desai B, Stasky AA, Hoelscher G, Hanley EN Jr. Human intervertebral disc cells from the annulus: three-dimensional culture in agarose or alginate and responsiveness to TGF- $\beta 1$. Exp Cell Res 1997;235:13-21.

27. Gan JC, Ducheyne P, Vresilovic E, Shapiro IM. Bioactive glass serves as a substrate for maintenance of phenotype of nucleus pulposus cells of the intervertebral disc. J Biomed Mater Res 2000;51:596-604.

28. Stern S, Lindenhayn K, Schultz O, Perka C. Cultivation of porcine cells from the nucleus pulposus in a fibrin/hyaluronic acid matrix. Acta Orthop Scand 2000;71:496-502.
29. Perka C, Arnold U, Spitzer RS, Lindenhayn K. The use of fibrin beads for tissue engineering and subsequential transplantation. Tissue Engineering 2001;7:359-61.

30. Rong Y, Sugumaran G, Silbert J, Spector M. Proteoglycans synthesized by canine intervertebral disc cells growth in a type I collagenglycosaminoglycan matrix. Tissue Engineering 2002;8:1037-47.

31. Sato M, Asazuma T, Ishihara M, Kikuchi T, Masuoka K, Ichimura S, Kikuchi M, Kurita A, Fujikawa K. An atelocollagen honeycomb-shaped scaffold with a membrane seal (ACHMS-scaffold) for the culture of annulus fibrosus cells from an intervertebral disc. J Biomed Mater Res 2003;64A:248-56.

32. Yang SH, Chen PQ, Chen YF, Lin FH. Gelatin/chondroitin-6-sulfate co-polymer scaffold for culturing human nucleus pulposus cells in vitro with production of extracellular matrix. J Biomed Mater Res Part B, in press.

33. Rooney P, Kumar S. Inverse relationship between hyaluronan and collagens in development and angiogenesis. Differentiation 1993;54:1-9.

34. Frean SP, Abraham LA, Lees P. In vitro stimulation of equine articular cartilage proteoglycan synthesis by hyaluronan and carprofen. Res Vet Sci 1999;67:183-90.

35. Sechriest VF, Miao YJ, Niyibizi C, WesterhausenLarson A, Matthew HW, Evans $\mathrm{CH}, \mathrm{Fu}$ FH, Suk JK. GAG-augmented polysaccharide hydrogel: a novel biocompatible and biodegradable material to support chondrogenesis. J Biomed Mater Res 2000;49:534-41. 